\title{
PENGALENGAN IKAN TUNA KOMERSIAL
}

Hari Eko Irianto*) dan Teuku Muamar Indra Akbarsyah"*)

\begin{abstract}
ABSTRAK
Indonesia merupakan salah satu negara pengekspor produk ikan tuna dalam kaleng. Terdapat berbagai jenis ikan tuna di perairan Indonesia yang dapat digunakan sebagai bahan baku untuk pengolahan produk ikan tuna kaleng. Secara garis besar pengolahan tuna kaleng yang dilakukan oleh pabrik pengalengan ikan di Indonesia adalah penerimaan bahan baku, penyiangan, penyusunan dalam rak, pemasakan pendahuluan, pendinginan, pembuangan kepala dan kulit ikan, pembersihan daging, pemotongan, pengisian ke dalam kaleng, penambahan medium, penutupan kaleng, sterilisasi, pendinginan dan pemeraman kaleng, pelabelan, dan pengepakan. Standar Nasional Indonesia yang harus diikuti di dalam pengolahan produk ikan tuna kaleng adalah SNI 01-2712-1992: Tuna dalam Kaleng, SNI 01-2712.1-1992: Bahan Baku Tuna dalam Kaleng, dan SNI 01-2712.2-1992: Penanganan dan Pengolahan Ikan Tuna dalam Kaleng.
\end{abstract}

KATA KUNCI: pengalengan, ikan tuna, sterilisasi

\section{PENDAHULUAN}

Ikan tuna termasuk komoditas utama dalam program Revitalisasi Pertanian, Perikanan dan Kehutanan (RPPK) yang telah dicanangkan oleh Presiden Republik Indonesia pada tanggal 11 Juni 2005. Revitalisasi tersebut merupakan strategi umum pemerintah untuk meningkatkan kesejahteraan petani, nelayan, dan petani-hutan; meningkatkan daya saing produk pertanian, perikanan dan kehutanan; serta menjaga kelestarian sumberdaya pertanian, perikanan dan kehutanan (Kementerian Koordinator Bidang Perekonomian, 2005). Tuna dan cakalang dipilih di dalam program revitalisasi karena produksinya masih dapat ditingkatkan, terutama di kawasan Timur Indonesia. Potensi pelagis besar secara nasional mencapai 1.165,36 ribu ton (Departemen Kelautan dan Perikanan, 2005). Disamping ikan tuna, komoditas lain yang masuk ke dalam program revitalisasi adalah udang dan rumput laut.

Ikan tuna dan sejenisnya sampai saat ini masih mendominasi ekspor produk perikanan Indonesia. Perkembangan perikanan tuna diikuti dengan berkembangnya industri pengolahan tuna, terutama di lokasi-lokasi sentra pendaratan tuna, seperti Muara Baru-Jakarta, Pelabuhan Ratu-Jawa Barat, CilacapJawa Tengah, Benoa-Bali dan Bitung-Sulawesi Utara. Pada umumnya tuna dipasarkan sebagai produk segar (didinginkan) dalam bentuk utuh disiangi (fresh whole gilled and gutted); sebagai produk beku dalam bentuk utuh disiangi (frozen whole gilled and gutted), loin (frozen loin) dan steak (frozen steak); dan produk dalam kaleng (canned tuna) (Departemen Kelautan dan Perikanan, 2005).
Produksi ikan tuna kaleng cenderung meningkat yang ditunjukkan oleh trend yang meningkat dari ekspor produk tuna kaleng. Ekspor tuna kaleng pada tahun 1999 sebanyak 36.264 ton dan meningkat menjadi 118.449 ton pada tahun 2004 dengan tingkat kenaikan rata-rata $7,27 \%$ per tahun (Direktorat Jenderal Perikanan Budidaya, 2006).Data tersebut mengindikasikan bahwa pasar ekspor untuk produk tuna kaleng cukup baik dan masih berpeluang untuk meningkat.

\section{Ikan Tuna sebagai Bahan Baku Ikan Kaleng}

Jenis-jenis ikan tuna yang digunakan sebagai bahan baku tuna kaleng menurut SNI-01-2712-1992 dapat dilihat pada Tabel 1. Di dalam statistik perikanan Indonesia, tuna digunakan sebagai nama grup dari beberapa jenis ikan yang terdiri dari jenis tuna besar dan jenis ikan mirip tuna. Jenis ikan yang termasuk ke dalam tuna besar (Thunnus spp) adalah yellow fin tuna, big eye, southern bluefin tuna, dan albacore. Sedangkan yang tergolong dalam jenis ikan mirip tuna (tuna -like species) adalah marlin, sailfish, dan swordfish. Skipjack tuna sering digolongkan sebagai cakalang, sedangkan istilah tongkol umumnya digunakan untuk jenis eastern little tuna (Euthynus spp), frigate dan bullet tuna (Auxis spp) dan longtail tuna (Thunnus tonggol) (Departemen Kelautan dan Perikanan, 2005).

Ikan tuna mempunyai bentuk seperti torpedo dengan kepala yang lancip, tubuhnya licin, sirip dada melengkung dan sirip ekor becagak dengan celah yang lebar. Di belakang sirip punggung dan sirip dubur terdapat sirip-sirip tambahan yang kecil-kecil dan

\footnotetext{
*) Peneliti pada Balai Besar Riset Pengolahan Produk dan Bioteknologi Kelautan dan Perikanan

*) Alumni Sekolah Tinggi Perikanan
} 
Tabel 1. Jenis ikan tuna yang dikalengkan

\begin{tabular}{lll}
\hline \multicolumn{1}{c}{ Nama Indonesia } & \multicolumn{1}{c}{ Nama Inggris } & \multicolumn{1}{c}{ Nama latin } \\
\hline Albakora & Albacore & Thunnus germo \\
Madidihang & Yellow fin tuna & Thunnus albacares \\
Tuna mata besar & Big eye tuna & Thunnus obesus \\
Tuna abu-abu & Blue fin tuna & Thunnus tonggol \\
Cakalang & Skipjack & Katsuwonus pelamis \\
Tongkol & Eastern little tuna & Euthynnus affinis \\
Setuhuk loreng & Striped marlin & Makaira mitsukurii \\
Setuhuk hitam & Black marlin & Makaira mazara \\
Setuhuk putih & White marlin & Makaira marlina \\
Ikan pedang & Sword fish & Xiphias gladius \\
\hline
\end{tabular}

Sumber : SNI-01-2712-1992

terpisah-pisah. Sirip-sirip punggung, dubur, perut dan dada, pada pangkalnya mempunyai lekukan pada tubuh. Sirip-sirip tersebut dapat dilipat masuk ke dalam lekukan itu, sehingga dapat memperkecil daya gesekan air pada saat ikan tuna itu sedang berenang dengan kecepatan penuh. Ikan tuna memang terkenal sebagai perenang-perenang yang hebat, bisa mencapai kecepatan sekitar $50 \mathrm{~km} / \mathrm{jam}$. Umumnya ikan-ikan tuna hidup dengan mengarungi samuderasamudera besar dunia (Nontji, 2002)

Komposisi kimia daging tuna bervariasi menurut jenis, umur, kelamin dan musim. Perubahan yang nyata terjadi pada kandungan lemak sebelum dan sesudah memijah. Kandungan lemak juga berbeda nyata pada bagian tubuh yang satu dengan yang lain. Ketebalan lapisan lemak di bawah kulit berubah menurut umur dan/atau musim. Lemak paling banyak terdapat di dinding perut (Murniyati \& Sunarman, 2000). Komposisi kimia daging tuna dapat dilihat pada Tabel 2.

Ikan tuna yang digunakan sebagai bahan baku pada pengolahan tuna kaleng harus memenuhi persyaratan seperti yang diuraikan dalam SNI 012712.1-1992, yaitu:

1. Bentuk bahan baku yang digunakan sebagai bahan baku pengalengan ikan tuna berupa tuna segar atau beku, utuh atau tanpa isi perut.

2. Bahan baku harus berasal dari perairan yang tidak tercemar.

3. Bahan baku harus bersih, bebas dari setiap bau yang menandakan pembusukan, bebas dari tanda

Tabel 2. Komposisi proksimat daging tuna (dalam \% berat)

\begin{tabular}{llcccc}
\hline \multicolumn{1}{c}{ Jenis tuna } & \multicolumn{1}{c}{ Sampel } & Air & Protein & Lemak & Abu \\
\hline Blue fin tuna & Daging merah & 68.7 & 28.3 & 1.4 & 1.50 \\
& Daging berlemak & 52.6 & 21.4 & 24.6 & 1.30 \\
Southern blue fin tuna & Daging merah & 65.6 & 23.6 & 9.3 & 1.40 \\
& Daging berlemak & 63.9 & 23.1 & 11.6 & 1.30 \\
Yellow fin tuna & Daging merah & 74.2 & 22.2 & 2.1 & 1.40 \\
Marlin & & 72.1 & 25.4 & 3 & 1.40 \\
Skipjack & & 70.4 & 25.8 & 2 & 1.40 \\
Mackerel & 62.5 & 19.8 & 16.5 & 1.10 \\
\hline
\end{tabular}

Sumber : Murniati \& Sunarman (2000) 
dekomposisi dan pemalsuan, bebas dari sifat alami lain yang dapat menurunkan mutu serta tidak membahayakan kesehatan.

\section{Jenis Produk Tuna Kaleng}

Ikan tuna dalam kaleng didefinisikan sebagai potongan daging putih ikan tuna yang telah mengalami pemasakan pendahuluan dan dikalengkan dalam medium minyak atau air garam (brine) (SNI-01-27121992). Dengan demikian berdasarkan jenis medium yang digunakan, produk ikan tuna kaleng dibedakan atas produk tuna in oil dan tuna in water/brine. Dua jenis produk tersebut merupakan produk tuna kaleng yang selama ini diproduksi dan dipasarkan oleh industri pengalengan Indonesia.

Perusahaan-perusahaan pengalengan tuna dapat membuat klasifikasi sendiri terhadap produk tuna kaleng yang dihasilkan. Sebagai contoh klasifikasi produk ikan kaleng yang dihasilkan oleh salah satu perusahaan pengalengan tuna kaleng di Indonesia adalah sebagai berikut:

1. TANS (Tuna Albacore Natural Solid) yaitu produk tuna kaleng dari ikan tuna albakora dengan daging berupa solid dan flake menggunakan medium air garam

2. TANC (Tuna Albacore Natural Chunk) yaitu produk tuna kaleng dari ikan tuna albakora dengan daging berupa layer, chunk dan flake menggunakan medium air garam.

3. TWNC (Tuna White Natural Chunk) yaitu produk tuna kaleng dari ikan baby tuna atau dikenal dengan sebutan SSWM (Sub Standar White Meat) dengan daging berupa layer, chunk dan flake menggunakan medium air garam.

4. TYNC (Tuna Yellow fin Natural Chunk) yaitu produk tuna kaleng dari ikan yellow fin tuna dengan daging berupa layer, chunk dan flake menggunakan medium air garam.

5. THS (Tuna Hot Spicy) yaitu produk tuna kaleng dari ikan yellowfin tuna dengan daging yang dipotong-potong sepanjang $\pm 2 \mathrm{~cm}$ mempunyai lebar $\pm 0,5 \mathrm{~cm}$ menggunakan medium bumbubumbu masakan, produk ini dipasarkan lokal dan biasanya digunakan dalam pembuatan Pizza Hut.

6. SJNC (Skip Jack Natural Chunk) yaitu produk tuna kaleng dari ikan tuna cakalang dengan daging berupa layer, chunk dan flake menggunakan medium air garam, dipasarkan lokal.

7. SJOC (Skip Jack Oil Chunk) yaitu produk tuna kaleng dari ikan tuna cakalang dengan daging berupa layer, chunk dan flake menggunakan medium minyak, dipasarkan lokal.

\section{Proses Pengalengan Ikan Tuna}

\section{Penerimaan bahan baku}

Pada umumnya bahan baku ikan tuna diterima oleh industri pengalengan dalam keadaan beku. Pemeriksaan mutu terhadap bahan baku yang diterima harus dilakukan (Suwanrangsi et al., 1995), minimal dengan pengujian organoleptik. Setiap bahan baku yang tidak memenuhi persyaratan harus ditolak atau digunakan untuk jenis pengolahan lain yang sesuai. Pembongkaran bahan baku dilakukan setelah pengujian terhadap suhu, kadar histamin, kadar garam dan organoleptik. Sampel diambil sebanyak 5\% dari total bahan baku. Selain itu dilakukan pengujian terhadap honeycomb, brosis dan parasit dengan menggunakan test pack. Pengujian dilakukan dengan cara mengambil 2 ekor sampel ikan tuna dan dikukus selama 1-2,5 jam tergantung ukuran ikan. Standar penerimaan bahan baku yang diterapkan oleh salah satu industri pengalengan di Indonesia adalah suhu $\leq$ $-2^{\circ} \mathrm{C}$, histamin $\leq 2,5 \mathrm{mg} \%$, kadar garam $\leq 1,5 \mathrm{mg} \%$, dan organoleptik $\geq 7$ (dari skala 1-9). Sedangkan untuk honeycomb, brosis dan parasit tidak boleh lebih dari $2,5 \%$ dari daging yang dikukus. Di samping itu kandungan histamin pada ikan tuna beku dipersyaratkan maksimal 20 mg\% (SNI 01-2710-1992).

Bahan baku yang memenuhi standar dibongkar dari mobil pengangkut dengan waktu tidak boleh lebih dari 3 jam dan langsung dibawa ke cold storage. Di dalam cold storage ikan tuna disusun dengan batasbatas antar bahan baku berupa palet-palet dari supplier yang berbeda dan bahan baku ini diberi tanda dengan lot, yaitu identitas bahan baku berdasarkan jumlah kedatangan. Suhu cold storage adalah $-18^{\circ} \mathrm{C}$. Untuk memudahkan pengeluaran, penyimpanan dibedakan sesuai jenis ikan dan penyimpanan dilakukan maksimal 2-3 bulan, tergantung dari order yang ada.

Sebelum diolah, ikan tuna harus dilelehkan terlebih dahulu. Pelelehan ikan tuna beku diawali dengan mengisi bak pelelehan dengan air sebanyak seperempat dari kebutuhan untuk mencegah kerusakan fisik pada ikan saat dijatuhkan dalam bak. Selama proses pelelehan berlangsung, air dialirkan secara terus menerus yang menyebar melalui pipapipa yang terdapat di atas bak pelelehan. Waktu pelelehan sangat tergantung dari ukuran dan volume ikan dalam satu bak

\section{Penyiangan}

Proses penyiangan diawali dengan pemotongan ikan tuna menggunakan gergaji. Tuna albakora dipotong menjadi 7-8 bagian dengan panjang $11 \mathrm{~cm}$, 
dan biasanya ukuran panjang potongan ikan disesuaikan dengan tinggi kaleng. Bagian potongan ikan terdiri dari 4 atau 5 bagian badan tengah, 1 bagian leher, 1 bagian kepala, dan 1 bagian ekor. Tuna albakora yang telah dipotong, kemudian diambil bagian isi perut dan insang dengan menggunakan pisau. Limbah dari penyiangan dimanfaatkan dengan mengolahnya menjadi tepung ikan. Selama proses penyiangan ikan disiram terus menerus melalui pipapipa air yang terdapat di atas conveyor.

\section{Penyusunan dalam rak}

Penyusunan ikan dalam rak dilakukan berdasarkan potongan bagian anggota tubuh ikan. Bagian badan ikan disusun terpisah dalam rak yang berbeda dari bagian ekor, kepala, dan leher. Bagian badan ikan disusun teratur secara vertikal, sedangkan bagian ekor, kepala dan leher disusun dalam keadaan terlentang dan diselang-seling.

Pemisahan susunan dalam rak ini diperlukan karena masing-masing bagian tersebut memerlukan waktu pemasakan pendahuluan (precooking) yang berbeda. Susunan ikan dalam rak diatur jaraknya agar tidak terlalu dekat, sehingga memudahkan sirkulasi uap panas dalam rak.

\section{Pemasakan pendahuluan}

Tujuan dari pemasakan pendahuluan ini adalah untuk memudahkan proses pembersihan daging ikan, mengurangi kandungan air, lemak, dan membuat daging ikan menjadi lebih kompak (Murniyati \& Sunarman, 2000).

Proses pemasakan pendahuluan dilakukan dengan memasukkan ikan yang telah disusun dalam rak ke dalam cooker yaitu tempat atau ruangan pemasakan yang memiliki pintu yang dapat ditutup rapat untuk mencegah pengeluaran uap yang terlalu banyak. Setelah itu dilakukan pembersihan daging ikan dengan menyemprotkan air melalui pipa-pipa yang terdapat di dalam cooker selama 10 menit. Tahapan selanjutnya adalah pengeluaran uap panas melalui pipa yang terdapat dalam cooker hingga mencapai suhu $100^{\circ} \mathrm{C}$. Jika suhu telah mencapai $100^{\circ} \mathrm{C}$, aliran uap panas dihentikan. Suhu dan waktu pemasakan dapat dilihat dengan menggunakan thermorecording atau termometer. Pengontrolan suhu dimaksudkan untuk menjaga keseimbangan antara lama pemasakan, suhu, mutu daging serta biaya produksi, karena pengukusan yang terlalu lama dan suhu yang terlalu tinggi dapat mempengaruhi rupa dan tekstur daging (Moeljanto, 1992).

Setelah proses pemasakan pendahuluan, ikan disemprot kembali dengan air melalui pipa dalam cooker selama 10 menit. Penyemprotan ini bertujuan untuk mendinginkan dan membuat daging ikan menjadi kompak. Penyemprotan dengan air dapat juga dilakukan di luar cooker, tetapi dikhawatirkan akan terjadi perubahan warna daging menjadi kuning. Waktu pemasakan pendahuluan sangat tergantung dari ukuran ikan serta berat bagian badan ikan yang dipotong-potong, yaitu sekitar 60-80 menit. Air yang dikeluarkan oleh ikan selama proses pemasakan pendahuluan adalah sekitar 17,5\% (Broek, 1965).

\section{Pendinginan}

Rak yang berisikan daging ikan yang telah masak dikeluarkan dari cooker dan diletakkan dalam ruang pendinginan dan membiarkannya dalam ruangan tersebut selama \pm 3 jam. Pendinginan ini bertujuan untuk membuat daging ikan lebih kompak dan padat sehingga memudahkan dalam proses pengolahan selanjutnya.

\section{Pembuangan kepala dan kulit ikan}

Proses pembuangan kepala ikan dilakukan dengan tangan setelah diambil daging yang terdapat di dalamnya. Proses pembuangan kepala ikan tuna albakora lebih mudah dilakukan karena bagian tubuh ikan telah dipotong-potong terlebih dahulu. Selanjutnya ikan diletakkan dalam talam dan diberi tanda berdasarkan bagian tubuhnya.

Proses pembuangan kulit dilakukan menggunakan pisau yang tajam dalam posisi tegak dengan cara mengikis kulit tersebut sesuai arah otot pada daging ikan. Hal ini bertujuan untuk mencegah terbuangnya daging ikan yang akan mempengaruhi rendemen. Pada tahapan ini juga dilakukan pembuangan tulang dan sisik.

\section{Pembersihan daging}

Pembersihan daging ikan bertujuan untuk memisahkan daging ikan dari daging gelap, tulang yang terdapat dalam daging dan sisik yang masih tersisa setelah proses skinning. Pembersihan daging ikan dilakukan menggunakan pisau yang tajam. Teknik yang digunakan hampir sama dengan proses pembuangan kulit yaitu mengikis daging ikan secara perlahan dengan mata pisau tegak. Proses pembersihan daging ikan menghasilkan beberapa bagian daging antara lain solid, chunk, flake, daging hitam, dan daging cucian.

Bagian daging ini nantinya disortir untuk memisahkan sisa daging hitam atau coklat yang masih ada, tulang, dan sisik. Pensortiran juga dimaksudkan untuk menghindari adanya brosis, honeycomb dan parasit pada ikan sehingga mutu ikan tetap terjaga. 


\section{Pemotongan daging}

Pemotongan dimaksudkan untuk memperoleh bentuk dan ukuran ikan yang sesuai dengan kalengnya. Proses pemotongan dilakukan menggunakan pisau yang tajam yang menghasilkan daging solid dan serpihan (flake). Daging solid yang merupakan hasil utama pemotongan dikikis dengan pisau dan menghasilkan serpihan yang nantinya diisikan ke dalam kaleng. Dalam proses pemotongan daging, chunk yang dihasilkan dari proses pembersihan daging ikan bisa dibuat menjadi daging serpihan.

\section{Pengisian daging ke dalam kaleng}

Pengisian daging ke dalam kaleng dilakukan dengan cara menata daging ikan ke dalam kaleng sesuai dengan tipe produk (solid, chunk, flake, standar, dan grated) seperti yang diperlihatkan pada Tabel 3.

Daging ikan tuna albakora yang diisikan adalah daging solid dan flake dengan kaleng yang digunakan berukuran $603 \times 408$. Standar pengisian untuk berbagai macam produk yang telah diterangkan sebelumnya dapat dilihat pada Tabel 4. Daging solid yang diisikan dalam satu kaleng berjumlah $2-3$ potongan, pengisian dilakukan sepadat mungkin dan sesuai dengan net weight, oleh karenanya ditambahkan flake untuk memenuhi persyaratan tersebut.

\section{Penambahan medium}

Seperti yang telah disinggung sebelumnya bahwa medium yang digunakan dalam pengalengan tuna adalah minyak nabati atau air garam. Pada medium minyak nabati biasanya ditambahkan garam sebanyak $2,8 \%$ dari berat medium (Angrenani, 1997). Penambahan medium dilakukan secara manual dan otomatis.

Pada penambahan medium air garam, mula-mula medium dimasukkan ke dalam kaleng sebanyak seperempatnya dan dibiarkan beberapa menit, yang bertujuan agar air garam dapat meresap ke dalam daging untuk memberikan rasa. Setelah itu dilewatkan pada conveyor dan kaleng secara otomatis akan terisi

Tabel 3. Tipe daging ikan tuna yang dikalengkan

\begin{tabular}{|c|c|}
\hline Tipe daging & Karakte ristik \\
\hline Solid & 1-2 potong daging putih, bebas serpihan \\
\hline Standar & 2-3 potong daging putih, serpihan maksimal $2 \%$ \\
\hline \multirow[t]{2}{*}{ Chunk } & $\begin{array}{l}\text { Serpihan daging putih + satu kali makan, serpihan flake } \\
\text { maksimum } 40 \%\end{array}$ \\
\hline & Potongan daging kecil <chunk \\
\hline Flake & Daging kecil (flake, tidak seperti pasta) \\
\hline Grated & Daging kecil (flake, tidak seperti pasta) \\
\hline
\end{tabular}

Tabel 4. Pengisian daging ikan dalam kaleng

\begin{tabular}{cccc}
\hline No & Nama produk & Nett weight (g) & Flake (\%) \\
\hline 1 & TANS & $1950-2000$ & $2-3$ \\
2 & TANC & $1950-1980$ & $18-20$ \\
3 & TWNC & $1950-1980$ & $18-20$ \\
4 & TYNC & $1950-1980$ & $18-20$ \\
5 & SJNC Lokal & $1800-1850$ & $30-35$ \\
6 & SJOC Lokal & $1800-1850$ & $30-35$ \\
\hline
\end{tabular}

Sumber : Akbarsyah (2006) 
air garam yang keluar melalui pipa-pipa saluran dari tempat pemasakan air garam yang terdapat di atas conveyor. Pengisian air garam tidak boleh berlebih, karena mempengaruhi kaleng pada saat penutupan dan dapat menyebabkan kaleng membengkak atau bocor. Oleh karena itu pengisian medium harus sampai batas head space atau $6-10 \%$ dari tinggi kaleng. Menurut SNI 01-2712.2-1992, suhu medium tidak boleh kurang dari $70^{\circ} \mathrm{C}$. Suhu air garam yang tinggi akan membuat kondisi vakum yang semakin tinggi. Pada suhu tinggi peluang udara yang terperangkap diantara bagian produk dalam kaleng lebih kecil (Winarno, 1994). Pengisian medium minyak nabati ke dalam kaleng dilakukan dengan cara yang sama seperti di atas.

\section{Penutupan kaleng}

Penutupan kaleng dilakukan dengan sistem double seaming secara otomatis menggunakan vacum seamer, yaitu mesin penutup kaleng yang sekaligus dapat melakukan penghampaan udara dalam kaleng. Dalam hal ini, kaleng yang telah berisikan ikan dan medium dilewatkan melalui conveyor menuju vacum seamer untuk dilakukan penutupan secara otomatis. Setiap kaleng yang ditutup dicek secara visual untuk melihat kesempurnaan proses penutupan kaleng. Adapun standar penutupan kaleng dapat dilihat pada Tabel 5.
Fo sesuai dengan jenis dan ukuran kaleng, media dan tipe produk dalam kemasan atau equivalent dengan nilai Fo $>2,8$ menit pada suhu $120^{\circ} \mathrm{C}$.

Setelah proses sterilisasi berakhir dilakukan pendinginan dengan menyemprotkan air yang mengandung khlorin 2 ppm selama \pm 30 menit. Penyemprotan bertujuan untuk mencegah terjadinya over cooking atau over processing yaitu ikan mengalami pemasakan lebih lanjut yang berakibat pada perubahan rasa, warna, dan tekstur daging.

\section{Pendinginan dan pemeraman kaleng}

Ikan tuna kaleng yang masih dalam keranjang sterilisasi didinginkan dalam ruang terbuka selama \pm 24 jam. Untuk mempercepat proses pendinginan, dalam ruangan tersebut dapat dipasang kipas angin. Ikan tuna kaleng yang telah dingin dibersihkan dengan minyak goreng untuk menghilangkan sisa-sisa kotoran pada kaleng. Disamping itu juga dilakukan pengecekan terhadap label pada tutup kaleng, jika ada yang terhapus dapat dilakukan penutupan ulang.

Ikan tuna kaleng tersebut selanjutnya dilakukan uji pemeraman untuk mengetahui kesempurnaan proses sterilisasi. Uji pemeraman menurut SNI-27121992, yaitu ikan kaleng yang telah dingin dimasukkan ke dalam suatu ruangan dengan suhu kamar dan diletakkan dengan posisi terbalik,

Tabel 5. Standar penutupan kaleng

\begin{tabular}{clc}
\hline No & \multicolumn{1}{c}{ Bagian kaleng } & Standar \\
\hline 1 & Countersink & $3.28 \pm 0.15 \mathrm{~mm}$ \\
2 & Thickness & $1.43 \pm 0.10 \mathrm{~mm}$ \\
3 & Width & $3.22 \pm 0.15 \mathrm{~mm}$ \\
4 & Body hook & $2.16 \pm 0.20 \mathrm{~mm}$ \\
5 & Can height & $113.78 \pm 0.30 \mathrm{~mm}$ \\
6 & Actual overlap (minimal) & $1.10 \mathrm{~mm}$ \\
7 & Tightness (minimal) & $75 \%$ \\
8 & End hook juncture (minimal) & $75 \%$ \\
\hline
\end{tabular}

Sumber : Akbarsyah (2006)

\section{Sterilisasi}

Proses sterilisasi diawali dengan penyusunan kaleng dalam keranjang sterilisasi. Selanjutnya keranjang dimasukkan dalam retort dan disemprot dengan air yang mengandung khlorin $2 \mathrm{ppm}$ selama 10 menit. Waktu dan suhu sterilisasi tergantung pada jenis produk dan kaleng yang disterilisasi seperti yang diperlihatkan pada Tabel 6. Menurut SNI 01-2712.21992, sterilisasi dilakukan di dalam retort dengan nilai kemudian dilakukan pengecekan terhadap kerusakan kaleng. Kaleng yang dianggap rusak adalah kaleng yang menggembung atau bocor. Pemeraman kaleng dilakukan minimal 7 hari.

\section{Pelabelan}

Pelabelan tuna kaleng dengan menggunakan kertas cetakan. Label berisikan keterangan tentang nama atau jenis ikan yang dikaleng, medium yang 
Tabel 6. Suhu dan waktu sterilisasi untuk beberapa tipe produk tuna kaleng

\begin{tabular}{lcccc}
\hline $\begin{array}{c}\text { Tipe produk } \\
\text { tuna kaleng }\end{array}$ & $\begin{array}{c}\text { Ukuran } \\
\text { kaleng }\end{array}$ & $\begin{array}{c}\text { Suhu minimal } \\
\text { bagian dalam }\left({ }^{\circ} \mathbf{C}\right)\end{array}$ & $\begin{array}{c}\text { Suhu sterilisasi } \\
\left({ }^{\circ} \mathbf{C}\right)\end{array}$ & $\begin{array}{c}\text { Waktu sterilisasi } \\
(\text { Menit) }\end{array}$ \\
\hline Solid in brine & $603 \times 408$ & 25 & $110 / 113 / 116$ & $234 / 199 / 174$ \\
Solid in oil & $603 \times 408$ & 25 & $110 / 113 / 116$ & $284 / 245 / 218$ \\
Chunk in brine & $603 \times 408$ & 25 & $110 / 113 / 116$ & $199 / 166 / 144$ \\
Chunk in oil & $603 \times 408$ & 25 & $110 / 113 / 116$ & $257 / 220 / 145$ \\
Flake in brine & $603 \times 408$ & 25 & $110 / 113 / 116$ & $274 / 235 / 280$ \\
Solid/Chunk in brine & $603 \times 408$ & 25 & $110 / 113 / 116$ & $121 / 94 / 78$ \\
Solid/Chunk in oil & $307 \times 112$ & 25 & $110 / 113 / 116$ & $128 / 101 / 84$ \\
Flake in oil & $603 \times 408$ & 25 & $110 / 113 / 116$ & $348 / 302 / 269$ \\
\hline
\end{tabular}

Sumber : Akbarsyah (2006)

digunakan, berat bersih, nama produsen, tanggal kadaluarsa, dan kandungan gizi. Untuk menghindarkan adanya kesalahan, setiap label di cek satu persatu sebelum digunakan. Pelabelan juga dapat dilakukan dengan mencetaknya langsung pada kaleng.

\section{Pengepakan}

Tuna kaleng dipak dalam master carton. Disain dari master carton disesuaikan dengan permintaan pembeli dan biasanya berisikan tentang tanggal produksi, jenis produk, jumlah kaleng, dan nama produsen. Master carton disimpan dalam gudang yang kering, dengan penerangan dan ventilasi yang cukup dan pada suhu kamar sampai menunggu proses distribusi.

\section{Mutu Ikan Tuna Kaleng}

Spesifikasi persyaratan mutu ikan tuna kaleng dapat dilihat pada Tabel 7. Pengujian mutu ikan tuna kaleng meliputi pengujian organoleptik, mikrobiologi, kimia dan fisik. Di dalam penilaian organoleptik terhadap ikan tuna kaleng dilakukan dengan cara memisahkan ikan dari mediumnya.

Tabel 7. Spesifikasi persyaratan mutu ikan tuna kaleng

\begin{tabular}{lc}
\hline \multicolumn{1}{c}{ Jenis uji } & Persyaratan mutu \\
\hline a) Organoleptik: & \\
- Nilai minimal & 6 \\
b) Mikrobiologi: & \\
1) TPC anaerob per g & 0 \\
2) TPC aerob per g & 0 \\
c) Kimia & \\
1) Stanum $\left.(\mathrm{Sn})^{*}\right) \mathrm{ppm}$ maks & 250 \\
2) Plumbum $\left.(\mathrm{Pb})^{*}\right)$ ppm maks & 5 \\
3) Arsen $(\mathrm{As})^{*} \mathrm{ppm}_{\text {maks }}$ & 1 \\
4) Mercuri $\left.(\mathrm{Hg})^{*}\right) \mathrm{ppm}$ maks & 0.5 \\
5) Histamin $\mathrm{mg} / 100 \mathrm{~g}$ maks & 20 \\
d) Fisika & \\
1) Fisika kaleng & Baik \\
2) Bobot tuntas (\%) & 70 \\
\hline
\end{tabular}

Keterangan : *) Bila diperlukan

Sumber : SNI-01-2712-1992 
Menurut SNI-01-2712-1992, nilai organoleptik untuk ikan tuna kaleng minimal adalah 6 . Persyaratan TPC untuk produk tuna kaleng yang meliputi bakteri aerob dan anaerob adalah nihil atau tidak ada, ini membuktikan bahwa proses sterilisasi yang dilakukan cukup sempurna. Kadar histamin produk ikan tuna maksimal $20 \mathrm{mg} / 100 \mathrm{~g}$.

\section{PENUTUP}

Ekspor produk ikan tuna kaleng Indonesia menunjukkan kecenderungan yang meningkat. Dari segi teknologi produksi tampaknya tidak mengalami permasalahan, tetapi hal yang perlu mendapat perhatian adalah kondisi sanitasi dan higiene dari pabrik pengolahan untuk menjamin keamanan produk yang dihasilkan serta pasokan bahan baku yang memenuhi persyaratan kualitas dan kuantitas. Dengan cara demikian industri pengalengan ikan tuna akan dapat bersaing di tingkat Internasional.

\section{DAFTAR PUSTAKA}

Akbarsyah, T.M.I. 2006. Studi proses pengalengan ikan tuna albakora (Thunnus alalunga) dan pemanfaatan limbahnya menjadi abon ikan di PT Bali Maya Permai, Negara, Bali. Karya IImiah Praktek Akhir Sekolah Tinggi Perikanan. Jakarta. 111 pp.

Angrenani, S. 1997. Stabilitas Minyak Ikan Lemuru (Sardinella lemuru) yang Digunakan Sebagai Medium pada Ikan Cakalang (Katsuwonus pelamis) Kaleng. Skripsi. Fakultas Perikanan, Institut Pertanian Bogor. Bogor. 87 pp.

Broek, C.J.H.V.D. 1965. Fish Canning. In : Fish as Food Vol. IV Procesing Part 2. (Ed. Borgstrom, G). Academic Press. New York. p. 127-205
Departemen Kelautan dan Perikanan. 2005. Revitalisasi Perikanan. Departemen Kelautan dan Perikanan. Jakarta. 80 pp.

Direktorat Jenderal Perikanan Budidaya. 2006. Statistik Ekspor Hasil Perikanan. Direktorat Jenderal Perikanan Budidaya. Departemen Kelautan dan Perikanan. Jakarta

Kementerian Koordinator Bidang Perekonomian. 2005. Revitalisasi Pertanian, Perikanan dan Kehutanan Indonesia 2005. Kementerian Koordinator Bidang Perekonomian. Jakarta. 56 pp.

Moeljanto, R. 1992. Pengawetan dan Pengolahan Hasil Perikanan. Penebar Swadaya. Jakarta. 259 pp.

Murniyati, S. dan Sunarman. 2000. Pendinginan, Pembekuan dan Pengawetan Ikan. Kanisius. Jakarta. 220 pp.

Nontji, A. 1993. Laut Nusantara. Penerbit Djambatan. Jakarta. 367 pp.

Standar Nasional Indonesia SNI 01-2712-1992: Tuna Dalam Kaleng. Dewan Standarisasi Nasional - DSN. Jakarta. 5 pp.

Standar Nasional Indonesia SNI 01-2712.1-1992: Bahan Baku Tuna Dalam Kaleng. Dewan Standarisasi Nasional - DSN. Jakarta. 6 pp.

Standar Nasional Indonesia SNI 01-2712.2-1992: Penanganan dan Pengolahan Ikan Tuna Dalam Kaleng. Dewan Standarisasi Nasional - DSN. Jakarta. $10 \mathrm{pp}$.

Suwanrangsi, S., Keerathuviriyaporn, S., Sophongphong, K., Briliantes, S. and Limpus, L.G. 1995. Canned Tuna Quality Management Manual. Asean Canada Fisheries Post-Harvest Technology Project-Phase II. Department of Fisheries. Bangkok. 203 pp.

Winarno, F.G. 1994. Sterilisasi Komersial Produk Pangan. PT Gramedia Pustaka Utama. Jakarta. 165 pp. 